\title{
A organização e as políticas do conhecimento ao longo do tempo: desbravando a Amazônia
}

\author{
Giulia Crippa \\ Doutora em História Social pela Universidade de São Paulo - USP \\ Professora do curso de Ciências da Informação e Documentação da FFCLRP/USP \\ E-mail: giuliac@ffclrp.usp.br
}

\section{MEIRELLES FILHO, João. Grandes expedições à Amazônia brasileira: 1500-1930. São}

Paulo: Metalivros, 2009. 241 p.

João Meirelles Filho, paulistano, formado em Administração de Empresas pela Fundação Getúlio Vargas, há tempo se dedica aos trabalhos do Instituto Peabiru, uma organização voltada para a realização de projetos de sustentabilidade na Amazônia, na qualidade de diretor, e à pesquisa e escritura de livros cujo tema é ligado a esse espaço geográfico. Já tem, com efeito, um longo histórico de livros, traduzidos também em outros idiomas, dedicados à Amazônia, mas o livro Grandes expedições à Amazônia brasileira, publicado pela Metalivro, é de interesse especial para a Ciência de Informação.

Esse trabalho aborda as questões ligadas à formação discursivo-científica da Amazônia, enfocando as relações institucionais que levaram à elaboração de produtos informacionais e de conhecimento sobre essa área geográfica particular. Apesar de escolher uma organização cronológica dos eventos tratados -expedições amazônicas de 1500 a 1930 -, o autor realiza sua pesquisa em uma perspectiva histórica que revela as vertentes e as rupturas epistêmicas que norteiam a constituição da ciência e do conhecimento modernos, revelando a não linearidade dos interesses econômicos, científicos e culturais que envolveram a descoberta, os estudos e o conhecimento de pesquisas orientadas por interesses diversos.

Com efeito, as explorações, as pesquisas e a consequiente elaboração de produtos informacionais não são dadas a priori, nem respondem, ao longo do tempo, às mesmas demandas de conhecimento. Elas são o resultado de formações históricas voltadas para a criação e manutenção de instituições conservadoras e disseminadoras, de forma organizada, dos instrumentos e materiais de conhecimento considerado relevante nas várias épocas.

Torna-se necessária uma reflexão em relação à figura e ao papel dos responsáveis pela produção dos documentos em cada época, na tentativa de constituir um urdido sólido para uma reformulação, no presente, do espaço da informação. Uma perspectiva histórica permite 
reconstituir o percurso das tarefas e responsabilidades de quem mapeou e construiu os conhecimentos sobre a Amazônia, para entendermos a relação entre manutenção e renovação das estruturas institucionais que se ocuparam e se ocupam da informação desse espaço. É, de fato, através de escolhas de políticas de exploração e de políticas de informação que se torna possível a produção de conhecimentos sobre a Amazônia.

O livro reconstitui as motivações e os roteiros de quarenta e duas viagens, desde a exploração do desbravador Pinzón em 1500 até as missões de Cândido Rondon, na década de 1930, identificando um tema comum que norteia essas viagens: a ampliação da cultura, não somente dos protagonistas, mas de curiosos, estudiosos, cientistas e empresários distantes no tempo e no espaço, que usufruíram dos diários, dos relatórios, dos mapas, dos desenhos, dos objetos, dos espécimes animais e vegetais e das fotografias que representaram, em uma operação de "redução"e de "ampliação" - para utilizar uma terminologia Latouriana -, o mundo distante, a diversidade e a peculiaridade da Amazônia, permitindo a apropriação de seu conhecimento e, eventualmente, a ampliação da exploração de seus recursos naturais.

Como o próprio autor frisa em sua introdução, a seleção da publicação visa sublinhar a idéia de viagem e não de viajante, pois se trata, sempre, de expedições compostas por um conjunto de participantes e investidas, com freqüência, de oficialidade institucional, que se torna, também, financiamento e cobrança de resultados.

A sequiência escolhida para a redação dos capítulos capta o interesse da ciência da informação na escolha dos temas que ilustram as viagem. À data da expedição, segue uma contextualização histórica que ilustra suas motivações socioeconômicas e culturais e os principais interesses da época em relação ao conhecimento. Segue a biografia do líder ou dos líderes, uma relação sobre os principais colaboradores, o roteiro seguido, a obra ou as obras que resultaram da viagem e, finalmente, as contribuições para os vários campos de conhecimento - geográfico, etnográfico, literário, fotográfico, museológico etc. - decorrentes da expedição.

No caso da viagem de Pinzón, observa-se a necessidade cartográfica que reforça as pretensões espanholas e portuguesas após o tratado de Tordesilhas. Ao mesmo tempo, é realçada a busca por "notícias" relativas às populações, à fauna e à flora local. Se trata, portanto, de um contexto histórico que visa conhecimento estratégico para as políticas de controle do território, através de seu mapeamento, assim como visa um conhecimento voltado para o conhecimento da Natureza do lugar. A viagem foi documentada pelos relatos de Pedro 
Mártir de Angleria e foi referencia para as pesquisas de Humboldt sobre a região em 1832, enquanto as contribuições das informações fornecidas pela expedição são visíveis no mapamúndi desenhado pelo cartógrafo espanhol Juan de la Cosa ainda em 1500.

A expedição cartográfica de Pedro Vicente Maldonado e de Condamine, realizada em 1743, revela um contexto histórico (portanto, de interesses econômicos e de políticas culturais e de "incentivo à pesquisa", para utilizar um linguajar contemporâneo) diferente. Colocam-se, na base da expedição, os interesses da Academie Royale des Sciences e noções científicas decorrentes das proposições newtonianas. Alem de várias obras publicadas pelos dois autores, relatando a viagem, as contribuições maiores dessa expedição foram para a área da cartografia e da geografia, mas também para a mineralogia. A área que mais se beneficiou dessa expedição foi, sem dúvida, a botânica, com a descoberta da presença da borracha e da quinina. Será exatamente a presença dessas duas plantas e de suas propriedades que mobilizarão novos interesses de pesquisa sobre a área e permitirão o financiamento de expedições justificadas por novas perspectivas de exploração econômicas. É nesse sentido que se realiza, por exemplo, a expedição do príncipe Adalberto de Prússia, que lidera, em 1842, uma viagem voltada exatamente para os interesses econômicos ligados à potencialidade da borracha.

A expedição de Alfred Russel Wallace, realizada entre 1848 e 1852, apoiada e financiada por instituições museais que procuram ampliar suas coleções naturalísticas, se torna crucial no debate sobre o evolucionismo, questão central para o conhecimento da época. Obras de cunho naturalista e geográfico decorrem dessa viagem que, além de contribuir para o incremento de coleções e para os conhecimentos mais estritamente naturalísticos, também revela, pela primeira vez, interesses sociais, típicos da sociedade vitoriana da época na qual atuava Wallace.

Encontramos, ainda, a presença de mulheres como lideres da exploração nos capítulos dedicados às viagens científica de Therese Wittelsbacher em 1888 e de Emilie Snethlage, entre 1905 e 1929, que testemunham mudanças na construção do conhecimento científico, aberto agora, entre mil dificuldades e preconceitos, às mulheres. Therese Wittelsbacher publica vários livros sobre sua experiência amazônica e contribui, com fartura de materiais, para o incremento das coleções botânicas, zoológicas e etnográficas do Museu da Baviera. Vale lembrar que o material que passa a integrar essas coleções desfruta também das possibilidade oferecidas pelo uso de registros fotográficos realizados pela própria Therese. A 
trajetória de Emilie Snethlage é particularmente interessante, e no livro é traçada uma biografia que realça um percurso acadêmico de grande destaque que sublinha seu pioneirismo e ousadia feminista em sua atuação como cientista. A própria Berta Lutz escreverá sobre ela, enaltecendo esses aspectos. Sua produção científica compreende dezenas de artigos e, principlmente, um catálogo das espécies de aves presentes no território, resultado de oito anos de pesquisa. Cientista e colecionadora dedicada, seu trabalho abasteceu os grandes acervos do Museu Goeldi, em Belém, fornecendo não menos de 10.000 peles de aves, do Museu Nacional e de outras instituições museais européias e norte-americanas.

As viagens contadas por Meirelles desenham, através de uma formulação clara e com um rico aparato de ilustrações, uma história das "políticas de informação" e das instituições que as sustentaram, bem como mapeiam o legado bibliográfico e material que constitui, guardado em bibliotecas e museus, a base do conhecimento resultante dos interesses das várias épocas. Essa perspectiva histórica, para o campo da ciência da informação, permite, sem dúvida, um enriquecimento das discussões acerca da constituição e da transformação do conhecimento e de seus produtos informacionais. 